УДК 378.147:81'25-051:378.4(71)

DOI: https://doi.org/10.35387/od.2(20).2021.109-117.

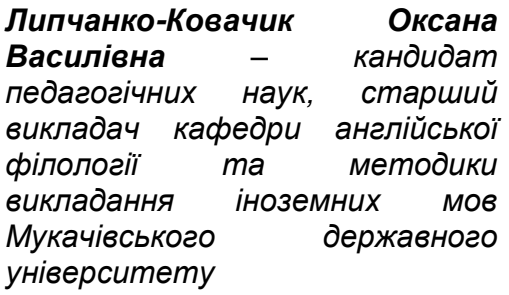

Lypchanko-Kovachyk Oksana Candidate of Pedagogical Sciences, Senior Lecturer of the English Philology Department of the Mukachevo State University

ORCID iD: https://orcid.org/0000-0003-3419-1717

E-mail: oksana.lypchanko@gmail.com

Кончович Катерина Тиберіївна

- кандидат педагогічних наук, старший викладач кафредри англійської фрілології та методики викладання іноземних мов Мукачівського державного університету

ORCID iD: https://orcid.org/0000-0001-8035-9205

E-mail: catbenz119@gmail.com

\begin{abstract}
Konchovych
Candidate of Pedagogical

Sciences, Senior Lecturer of the English Philology Department of the Mukachevo State University
\end{abstract}

Варга Леся Іванівна - кандидат
педагогічних наук, старший
викладач кафедри англійської
фрілології та та методики
викладання іноземних мов
Мукачівського
університету

ORCID iD: https://orcid.org/0000-0002-0746-1593

E-mail: lesja.varga@gmail.com

\title{
ФОРМУВАННЯ ГОТОВНОСТІ МАЙБУТНІХ УЧИТЕЛІВ ІНОЗЕМНОЇ МОВИ ДО ОРГАНІЗАЦІЇ КОМУНІКАТИВНОГО ПРОЦЕСУ У ПРОФЕСІЙНІЙ ДІЯЛЬНОСТІ
}

\footnotetext{
Анотація. В оглядовій статті обгрунтовано сутність і визначено основні складові комунікативного процесу. Конкретизовано умови спілкування. Розкрито сутність способів поводження з комунікативним партнером, серед яких виокремлюються співробітництво, партнерство, домінування, маніпуляція, конфлікт. Зазвичай комунікація розглядається науковцями як складне явище і важливий чинник впливу на соціальні процеси. Вербальна комунікація відбувається як цілеспрямований процес створення,
} 
передавання та інтерпретації повідомлень засобами мови (мовного коду). Саме цей аспект міжособистісної взаємодії втілюється в комунікативний процес, який має складний динамічний характер, $\epsilon$ соціолінгвістичним комплексом, безперервною взаємодією учасників комунікації. Акцентовано увагу на доцільності використання інтерактивних технологій у підготовці майбутніх вчителів іноземної мови, як оптимального навчального середовища для опануванням студентами вміннями і навичками організації ефрективного комунікативного процесу. В ході наукової розвідки принципами вербальної взаємодії визначено принцип ввічливості, тобто взаємоприхильності комунікантів, та принцип кооперації - взаємного оперування інфрормацією. Спосіб поводження з комунікативним партнером будується за канонами комунікативної поведінки. Апробувати оптимальні зразки способів поводження з комунікативним партнером у подальшый профресійній діяльності майбутні вчителі іноземної мови мають змогу шляхом активної участі в інтерактивних ситуаціях фахового спрямування під час здобуття вищої освіти. Авторами статmі узагальнено, що організація комунікативного процесу має складний динамічний характер $i$ визначається безперервною взаємодією учасників комунікації.

Ключові слова: майбутні вчителі; профресійна діяльність; комунікативний процес; спілкування; комуніканти; інтерактивні технології.

\title{
Lypchanko-Kovachyk Oksana, Konchovych Kateryna, Varga Lesya
}

\section{FORMATION OF FUTURE FOREIGN LANGUAGE TEACHERS' READINESS FOR ORGANIZATION OF COMMUNICATIVE PROCESS IN THEIR PROFESSIONAL ACTIVITY}

\begin{abstract}
The article substantiates the essence and identifies the main components of the communicative process. The conditions of communication have been specified. The essence of ways of collaboration with a communicative partner has been revealed, among which the following: cooperation, partnership, domination, manipulation, conflict are singled out. Communication is usually considered by scientists as a complex phenomenon and an important factor of influencing social processes. Verbal communication occurs as a purposeful process of creating, transmitting and interpreting messages by means of language (language code). It is this aspect of interpersonal interaction that is embodied in the communicative process, which has a complex dynamic nature, is a sociolinguistic complex, continuous interaction of communication participants. Emphasis has been placed on the feasibility of using interactive technologies in the preparation of future foreign language teachers, as the optimal learning environment for students to master the skills and abilities to organize an effective communication process. In the course of scientific intelligence, the principles of verbal interaction determine the principle of politeness, for instance mutual commitment of communicators, and the principle of cooperation - mutual operation of information. The way of dealing with a communicative partner is based on the canons of communicative behavior. Students have the opportunity to test the best examples of ways to deal with a communicative partner in the professional activities of future foreign language teachers by actively
\end{abstract}


participating in interactive situations of professional orientation during higher education. The authors of the article generalize that the organization of the communicative process has a complex dynamic nature and is determined by the continuous interaction of communication participants.

Key words: future teachers; professional activity; communicative process; communication; communicators; interactive technologies.

Постановка проблеми, їі актуальність. Діяльнісно-інтеракційна парадигма тлумачить комунікацію як спільну діяльність її учасників (комунікантів), у процесі якої вони виробляють спільні погляди на речі та дії з ними. Діяльнісно-інтеракційному підходу властиве врахування людського чинника, взаємодії та взаємин між учасниками акту комунікації. На думку багатьох прихильників цього підходу, комунікація - це процес значно масштабніший, ніж звичайний обмін інформацією, оскільки вона охоплює широке коло зв'язків і відношень (між адресантом та адресатом, особистісна позиція відправника повідомлення до соціальної реальності, теми, ситуації спілкування тощо). У межах діяльнісно-інтеракційного підходу комунікацію тлумачать як особливу мовленнєву діяльність (Семенюк, 2010, с. 34).

Основним засобом комунікації $€$ мова, яка забезпечує обмін інформацією між індивідами, індивідом і суспільством, групами індивідів, навіть автокомунікацію - комунікацію людини з собою. Тому майбутні бакалаври-філологи, які здобувають вищу освіту, і професійна діяльність котрих здебільшого базується на комунікативній взаємодії, зобов'язані володіти теорією і практикою мовної комунікації.

Аналіз актуальних досліджень i публікацій дає змогу встановити, що на основі теоретичних надбань науковців визначається комунікативний та інтерактивний аспект спілкування як процесу обміну інформацією та як процесу взаємодії (Андреева, 2002). Дослідники проводили діагностику здібностей особистості до спілкування (Батаршев, 2006), використовували інноваційні підходи до навчання спілкуватися засобами комунікаційного тренінгу (Биркенбиль, 2002) та ін. Водночас науковці стверджують, що випускників ВНЗ не готують до свідомого конструювання своїх взаємовідносин із різними професійними комунікативними партнерами за допомогою мовних засобів (вербальних і невербальних), а також цілеспрямовано не навчають ефективних прийомів спілкування задля ефективної координації спільної діяльності та побудови взаєморозуміння з професійними партнерами (Чорній, 2011, с. 14).

Мета статті полягає в тому, щоб конкретизувати складові комунікативного процесу, які необхідно враховувати майбутнім бакалаврам-фрілологам у майбутній професійній діяльності.

Виклад основного матеріалу дослідження. Зазвичай комунікація розглядається науковцями як складне явище і важливий чинник впливу на соціальні процеси. Вербальна комунікація відбувається як цілеспрямований процес створення, передавання та інтерпретації повідомлень засобами мови (мовного коду). Саме цей аспект 
міжособистісної взаємодії втілюється в комунікативний процес, який має складний динамічний характер, $€$ соціолінгвістичним комплексом, безперервною взаємодією учасників комунікації.

Науковцями комунікативний процес окреслюється як «форма об'єктивації вербальної комунікації, за якої комуніканти вступають у вербальний контакт засобами мовного та позамовних кодів з приводу референта (об'єкта, про який ідеться), продукуючи та інтерпретуючи повідомлення (дискурс) згідно з комунікативними намірами (інтенціями) та 3 урахуванням контексту, використовуючи певні комунікативні ресурси (стратегії і тактики) для досягнення комунікативних цілей» (Семенюк, 2010, с. 16).

Для організації оптимального та ефективного комунікативного процесу майбутні бакалаври-фрілологи зобов'язані чітко визначати його структуру. Комунікативний процес як складний соціолінгвістичний комплекс утворюють такі складові: комуніканти, вербальний контакт, мовний код, комунікативні ресурси, позамовні коди.

Розглянемо сутність кожної із складових комунікативного процесу.

Комунікантами (homo loquens - людина, яка говорить) $є$ особи, які беруть участь у комунікації. Науковці стверджують, що комунікант вступає в комунікацію не як глобальна особистість, у якій поєднано всі її складники, а як особистість «параметризована» (Арутюнова, 2003), що «виявляє в комунікативному акті різноманіття своїх ролей (позицій), у зв'язку з якими і має розглядатися іï висловлювання» (Семенюк, 2010, с. 16). Тому комунікативну особистість доцільно вивчати як парадигму особистостей (ролей, позицій), яким властиві різні комунікативно-мовні підсистеми та комунікативні ресурси, що вступають у взаємодію з такими самими підсистемами партнера-комуніканта залежно від умов спілкування. Таким чином відбувається вербальний контакт.

Останнім часом у наукових колах поширюються ідеї фрілософііі діалогізму, які пов'язуються з іменем відомого літературознавця і лінгвіста М. Бахтіна. Науковець стверджує, що для розуміння процесу комунікації доцільно враховувати два основних фрактори. По-перше, необхідною ознакою будь-якого висловлювання $€$ його адресованість, тобто, без слухача розмова втрачає свій сенс. По-друге, будь-яке висловлювання набуває сенсу тільки в певному контексті, в конкретний час і в конкретному місці (ідея хронотопа, що означають «час» і «місце»).

Таким чином, вербальний контакт розглядається як фрагмент комунікативного процесу, обмежений початком та кінцем вербальної взаємодії двох або більше комунікантів у певний час і в певному місці. У процесі вербального контакту організовується обмін комунікативними діями, спрямований на досягнення комунікативної мети, який зазвичай відбувається згідно 3 принципами та правилами комунікативного кодексу. Найзагальнішими принципами вербальної взаємодії визнаються принцип ввічливості, тобто взаємоприхильності комунікантів, та принцип кооперації взаємного оперування інформацією. Навчити майбутніх фрілологів дотримуватися окреслених принципів можна шляхом використання інтерактивних технологій, які засновані на активній міжособистісній взаємодії. 
У процесі комунікативної взаємодії комуніканти використовують сукупність мовних засобів для створення обміну повідомленнями під час вербальної взаємодії (спілкування, комунікації), що має назву вербальний (мовний) код. Користування мовним кодом вимагає від комунікантів навичок володіння такими видами мовленнєвої діяльності, як слухання (аудіювання) і говоріння, які застосовують в усному спілкуванні, та читання і письмо - у писемній комунікації.

Слід зазначити, що науковці чітко визначили частку комунікації та iї складових у житті людини. Так, комунікація охоплює $80 \%$ усього існування людини, при цьому аудіювання - $45 \%$, говоріння - $30 \%$, читання - $16 \%$, письмо - 9 \% (Семенюк, 2010, с. 18). Таким чином, у підготовці бакалаврів-фрілологів особливу увагу необхідно приділяти навчанню студентів слухати і висловлюватися у процесі діалогічної взаємодії, що уможливлюється шляхом використання інтерактивних технологій та навчання фрахівців цього профрілю застосовувати інтеракції у майбутній професійній діяльності.

Зазвичай шлях фрізичного передавання повідомлення, засіб, за допомогою якого передаються повідомлення визначається як канал комунікації. У цьому контексті Г. Почепцов зауважує, що комунікація у людини може відбуватися переважно в межах двох основних каналів вербального і візуального (Батаршев, 2006). Саме в межах цих каналів комунікації у людини розвинулися найдосконаліші апарати продукування та аналізу повідомлень, доповненні відповідними механізмами запам'ятовування.

Доцільно розрізняти поняття «повідомлення» та «комунікація». Повідомлення здебільшого орієнтоване на відповідного адресанта, а в комунікації обов'язковою $є$ наявність зворотного зв'язку, що відображає реакцію на повідомлення з боку адресанта. Саме зворотний зв'язок $є$ тим засобом, який дає змогу дотримуватися визначеної лінії комунікації та сприяє організації розмови на певну тематику.

Науковці стверджують, що предметно-знаковим носієм повідомлення $є$ дискурс. Так, Ф. Бацевич характеризує його як певний тип комунікативної діяльності, як інтерактивне явище, мовленнєвий потік, що має різні форми вияву (усні, писемну), відбувається у межах конкретного каналу спілкування, регулюється стратегіями і тактиками учасників спілкування (Бацевич, 2002); це мова, яка «занурена в життя» (Семенюк, 2010 , с. 19). Таке розуміння дискурсу актуалізує використання у навчанні студентів педагогічних технологій інтерактивного характеру, за допомогою яких уможливлюються процеси моделювання ситуацій комунікативної взаємодії, які, наприклад, є зразками, життєвих, педагогічних, навчальновиховних ситуацій.

Елементарною, недискретною (неподільною) одиницею вербальної комунікації (дискурсу) $є$ мовленнєвий акт, сутність якого визначається як цілеспрямована мовленнєва дія, котра здійснюється згідно з принципами і правилами мовленнєвої поведінки і реалізує комунікативну інтенцію мовця. Зробити апробацію оптимальних зразків мовленнєвої 
поведінки студенти мають змогу шляхом участі у змодельованих ситуаціях комунікативно-інтерактивної взаємодії ще під час навчання у вищій школі. Таким чином, у майбутніх бакалаврів-фрілологів формуватимуться комунікативні ресурси - сукупність мовленнєвих та не мовленнєвих дій комуні кантів у межах вербального контакту, які спрямовані на досягнення комунікативної мети (стратегічного результату) певного комунікативного акту (Семенюк, 2010, с. 20).

Саме в умовах інтерактивної взаємодії під час використання спеціальних інтеракцій у студентів зростатимуть комунікативні ресурси, до яких зараховуються комунікативні стратегії та комунікативні тактики, пов'язані з комунікативною поведінкою співрозмовників. Використати весь багаж комунікативних ресурсів майбутні вчителі іноземної мови матимуть змогу шляхом реалізації окремих комунікативних актів, які в сукупності утворюють комунікативний процес.

Науковці конкретизують сутність комунікативного акту як концептуально і структурно організованого обміну комунікативною діяльністю мовцями у межах вербального контакту, в якому предметнознаковим носієм є дискурс, що опирається на певну ситуацію (Семенюк, 2010 , с. 23). Зазначене розуміння комунікативного акту актуалізує застосування у процесі фрахової підготовки майбутніх вчителів іноземної мови інтерактивних педагогічних технологій 3 використанням змодельованих ситуацій (фрагментів об'єктивно існуючої реальності, частиною якої може бути і вербальна дія), в яких студенти набуватимуть практичного досвіду організації оптимальної комунікативної взаємодії. Для участі в таких ситуаціях студенти повинні активізувати не тільки мовленнєву, а й мисленнєву діяльність. У зазначеному сенсі слушною $є$ думка науковців, що дискурс виражає вербалізовану мовленнєвомисленнєву діяльність комунікантів у межах вербального контакту, пов'язану з пізнанням, осмисленням і презентацією світу мовцем (адресантом) та осмисленням його мовної картини світу слухачем (адресатом) (Семенюк, 2010, с. 24). Інакше кажучи, дискурс доцільно розглядати як мовлення у розумінні цілеспрямованої соціальної дії, як компоненту, що бере участь у взаємодії суб'єктів спілкування та механізмах їхньої свідомості.

Для організації цілеспрямованої соціальної дії як компоненту, що бере участь у взаємодії суб'єктів спілкування та механізмах їхньої свідомості. ефективного комунікативного процесу 3 досягненням окреслених результатів у подальшій професійній діяльності майбутнього вчителя студенти ще під час навчання у ЗВО зобов'язані навчитися враховувати всі умови спілкування:

- діалогічність чи полілогічність комунікативного акту;

- залежність специфіки спілкування від просторово-часових відносин міжособистісної взаємодії («обличчям до обличчя» чи опосередковано, наприклад, по телефону);

- соціальні відносини комунікантів: а) симетричні, коли комуніканти володіють приблизно однаковим набором соціальних характеристик 
(наприклад, спілкування на рівні «учитель - учитель», «учитель - батьки учня» та ін.); б) асиметричні, коли комуніканти відрізняються антропологічно (за статтю чи віком, наприклад, на рівні «учитель - учні»); соціокультурно (наприклад, за взаєминами в певних соціальних інститутах, установах, організаціях тощо); професійно (за посадами або компетенцією); різним функціями у діалозі (наприклад, в інтерв'ю) та ін.;

- рівень підготовленості комунікантів;

- ступінь формальності у взаємодії комунікантів, що визначає їхнє спілкування або як офіційну інтеракцію, або як неформальне міжособистісне спілкування;

- способи поводження з комунікативним партнером, серед яких виокремлюються:

а) співробітництво, в основі якого ставлення до комунікативного партнера як до самоцінності, намагання об'єднати зусилля в спільній діяльності для досягнення певних цілей;

б) партнерство - ставлення до комунікативного партнера як до рівного;

в) домінування - ставлення до партнера як до засобу досягнення власних цілей, відкрите ігнорування його інтересів, намагання отримати необмежену односторонню перевагу;

г) маніпуляція - здійснення прихованого впливу на партнеракомуніканта з метою отримання переваг над ним;

д) конфлікт - коли метою вербальної взаємодії визначається завдавання моральних збитків партнеру по комунікації, а в її основі реальні або ілюзорні суперечності цілей комунікантів при спробі їх вирішення на тлі гострих емоційних станів (Семенюк, 2010, с. 26).

Спосіб поводження 3 комунікативним партнером будується за канонами комунікативної поведінки. Апробувати оптимальні зразки способів поводження з комунікативним партнером у професійній діяльності майбутніх вчителів іноземної мови студенти мають змогу шляхом активної участі в інтерактивних ситуаціях фахового спрямування під час здобуття вищої освіти.

Висновки і перспективи подальших досліджень. Організація комунікативного процесу має складний динамічний характер і визначається безперервною взаємодією учасників комунікації. Комунікативний процес утворюють такі складові: комуніканти, вербальний контакт, мовний код, комунікативні ресурси, позамовні коди. Для опанування студентами вміннями і навичками створювати оптимальну комунікативну взаємодію в майбутній професійній діяльності необхідно використовувати у підготовці бакалаврів-фрілологів інтерактивні технології. Саме в умовах інтерактивної взаємодії під час використання спеціальних інтеракцій у студентів зростатимуть комунікативні ресурси, до яких зараховуються комунікативні стратегії та комунікативні тактики, пов'язані 3 комунікативною поведінкою співрозмовників. Використати весь багаж комунікативних ресурсів майбутні бакалаври-філологи матимуть змогу шляхом реалізації окремих комунікативних актів, які в сукупності утворюють комунікативний процес. 
Перспективи подальших досліджень вбачаємо в аналізі готовності вчителів іноземної мови до організації комунікативного процесу у професійній діяльності в цілому та на уроках іноземної мови зокрема.

На нашу думку, формування готовності майбутніх вчителів іноземної мови до організації комунікативного процесу у професійній діяльності засобами інформаційних технологій є перспективним напрямом подальших наукових досліджень.

\section{Список використаних джерел}

Андреева, Г. М. (2000). Общение как обмен информацией (коммуникативная сторона общения); Общение как взаимодействие (интерактивная сторона общения) / Г. М. Андреева (Ред.) Психология влияния. СПб.: Питер, 99-114.

Арутюнова, Н. Д. (2003). Предложение и его смысл: Логико-семантические проблемы. Москва. 383.

Батаршев, А. В. (2006). Диагностика способности к общению. Питер, 2006. 176.

Бацевич, Ф.С.(2002). Термінологія комунікативної лінгвістики: аспекти дискурсивного підходу. Вісник нац. ун-ту «Львівська політехніка». 1219.

Биркенбиль, В. Ф. (2002). Коммуникационный тренинг: наука общения для всех. Москва. 352.

Почепцов, Г. Г. (2001). Теория коммуникации. Москва. 256.

Семенюк, О. А., Паращук В. Ю. (2010). Основи теорії мовної комунікації : навч. посіб. Київ: ВЦ «Академія». 240.

Чорній В. Я. (2011). Формування готовності до професійного спілкування майбутніх фахівців фрінансово-економічної сфрери: дис. ... канд. пед. наук : 13.00.04. Тернопіль. 324.

\section{References (translated and transliterated)}

Andreeva H. M. (2000). Obsluhovuvannya yak obmin informatsiyeyu (komunikatyvna storona suspilstva) [Communication as information exchange (communicative side of communication)]. Obshchenye kak vzaymodeystvye (ynteraktyvnaya storona obshchenyya) [Communication as interaction (interactive side of communication)]. Psikhologiya vliyaniya The psychology of influence. SPb.: Pyter, 2000. 99-114 [in Russian].

Arutyunova N. D. (2003). Predlozhenye y eho smysl: Lohiko-semantychni problem [Sentence and its meaning: Logical and semantic problems]. 3-e yzd., Ster. M. : Edytoryal URSS, 2003. 383 [in Russian].

Batarshev A. V. (2006). Diahnostyka zdibnostey do suspilstva [Diagnosis of the ability to communicate]. SPb. : Pyter, 2006. 176 [in Russian].

Batsevych F. S. (2002). Terminolohiya komunikatyvnoyi linhvistyky: aspekty dyskursyvnoho pidkhodu [Terminology of communicative linguistics: aspects of the discursive approach]. Visnyk nats. un-tu «Lvivska politekhnika». 2002. 12-19 [in Ukrainian].

Byrkenbyl V. F. (2002). Komunikatsiynyy treninh: nauka suspilstva dlya vsikh; per. s nem. N. Chupeeva [Communication training: the science of communication for all]. M.: FAYR-PRESS, 2002. 352 [in Russian].

Pocheptsov H. H. (2001). Teoryya kommunykatsyy [Theory of communication]. M.: 
Refl-buk; K. : Vakler, 2001. 256 [in Ukrainian].

Semenyuk O. A., Parashchuk V. YU. (2010). Osnovy teoriyi movnoyi komunikatsiyi: navch. posibnyk [Fundamentals of the theory of speech communication]. K.: VTS «Akademiya», 2010. 240 [in Ukrainian].

Chorniy V. YA. (2011). Formuvannya hotovnosti do profesiynoho spilkuvannya maybutnikh fakhivtsiv finansovo-ekonomichnoyi sfery: dys. ... kand. ped. nauk: 13.00.04 [Formation of readiness for professional communication of future specialists of financial and economic sphere]. Ternopil, 2011. 324 [in Ukrainian].

УДК 37.377

DOI: https://doi.org/10.35387/od.2(20).2021.117-125

\begin{abstract}
Нечепорук Яна Сергіївна кандидат педагогічних наук, докторант кафредри педагогіки та менеджменту освіти Центральноукраїнського державного педагогічного університету імені Володимира Винниченка
\end{abstract}

\begin{abstract}
Necheporuk Yana - Candidate of Pedagogical Sciences, Doctoral Student of the Pedagogy and Education Management Department of the Volodymyr Vynnychenko Central Ukrainian State Pedagogical University in Kropyvnytskyi
\end{abstract}

ORCID iD: https://orcid.org/0000-0003-1152-8030

E-mail: yananecheporuk83@gmail.com

\section{ІННОВАЦІЙНІ ТЕНДЕНЦІЇ ТЕСТУВАННЯ У СФЕРІ ІНШОМОВНОї ПІДГОТОВКИ АВІАЦІЙНИХ ФАХІВЦІВ}

Анотація. Стаття присвячена аналізу інноваційних тенденцій тестування майбутніх $і$ діючих авіаційних фрахівців. Досліджено процес впровадження Вимог щодо володіння професійною мовою (LPR) та зазначено, що значну кількість тестів на знання авіаційної мови було розроблено та впроваджено кожним суб’єктом надання освітніх послуг окремо. Підкреслено, що незважаючи на те, що їх розроблення, можливо, здійснено у відповідь на LPR ICAO відповідно до керівних матеріалів, викладених у Документі ICAO 9835, вони мають відмінності у тлумаченні основного матеріалу, методах тестування та, власне, у тому, що є ефективним тестовим інструментом LPR. Це зумовило відмінності у стандартах і практиках їх апробації. У статті висвітлено низку проблем, які можуть свідчити про недостатність ефрективності іншомовної підготовки LPR ICAO, що може поставити під загрозу безпеку авіації.

У статті обгрунтовано актуальність і доцільність підвищення рівня профресійної іншомовної підготовки спеціалістів з цивільної авіації, а також критерії оцінки мовної компетентності. Висвітлено особливості авіаційної англійської мови для ведення радіопереговорів та їх вплив на безпеку польотів. Зауважено, що авіаційне профресійне спілкування набуває все більшого значення, а методи його підготовки та перевірки постають як 